STAKEHOLDER THEORY CLASSIFICATION, DEFINITIONS AND ESSENTIAL

CONTESTABILITY

Dr. Samantha Miles

Reader in Accounting and Finance, Research Lead Accounting, Finance and Economics

Faculty of Business, Oxford Brookes University, Headington Campus, Oxford, OX3 OBP, UK, svmiles@brookes.ac.uk 


\title{
STAKEHOLDER THEORY CLASSIFICATION, DEFINITIONS AND ESSENTIAL \\ CONTESTABILITY
}

\begin{abstract}

\section{Purpose}

Recognising the stakeholder concept as an essentially contested concept subject to multiple competing interpretations, this chapter presents a systematic meta-theory level conceptual analysis of stakeholder theory. A conceptual enquiry is required for optimal development of stakeholder theory: to reduce conceptual confusion and prevent stakeholder theory from developing into an accumulation of disparate ideas.
\end{abstract}

\section{Methodology}

A bounded systematic review was undertaken to extract the extant range of stakeholder definitions. Using a meta-level conceptual enquiry the definitions were deconstructed and analysed to establish how these relate to variants of stakeholder theory.

Determinants of the stakeholder concept were reconstructed, sorted, filtered and ordered to produce a comprehensive, multidimensional classification of stakeholder theory which was then subjected to empirical testing.

\section{Findings}

593 different stakeholder interpretations were identified, analysed, sorted and ordered into a classification model based on 4 hyponyms leading to 16 definitional categories. The classification was tested with positive results.

\section{Limitations}

The conceptual enquiry focuses exclusively on management literature: Alternative worldviews may propose alternative variables/classifications.

\section{Originality}

Stakeholder theory has been accused of being an umbrella concept rather than a distinct theory per se. The proposed classification, based on an unparalleled systematic review and meta-level analysis of stakeholder definitions, clearly indicates that stakeholder theory is a single theory. Through the analysis of multi-contextual contributions to 
stakeholder theory, an invaluable overview of what we know about stakeholder theory is presented in one model, illustrating how contributions are aligned and interrelated and thereby prescribing what is acceptable (unacceptable) as inclusion within stakeholder theory.

KEYWORDS: Conceptual enquiry, Essentially contested concept, Meta-theory, Stakeholder definitions, Stakeholder classification. 
Central to stakeholder theory is the concept of the stakeholder, but what is a stakeholder? This appears a simple question but is not one that has been answered with any degree of consensus. The lack of consensus arises from the very nature of stakeholder theory, as an amalgamation of eclectic narratives (Gilbert and Rasche, 2008) spanning strategic management, business ethics, marketing, human resource management, finance and corporate governance as well as far reaching adoption outside of business disciplines. Widely different conceptualisations of stakeholder theory and stakeholder definitions have emerged from these narratives as different definitions and approaches are generated to serve different purposes (Freeman, Harrison, Wicks, Parmar, and DeColle, 2010), each focusing on attributes that are relevant to context. As a consequence hundreds of stakeholder definitions exist (Miles, 2011).

Such profusion is testimony to the appeal of stakeholder theory but it is also "one of its prominent theoretical liabilities" (Phillips, Freeman and Wicks, 2003:479) and an issue that opponents, such as Sternberg (1997) are quick to criticize. There have been numerous calls made by academics (e.g. Freeman et al., 2010; Friedman and Miles, 2006; Kaler, 2003; Miles, 2012, 2015; Starik, 1995) seeking further clarification of the definition in order to advance stakeholder theory, as "It is by defining what is and what is not a stakeholder that we create the reality of whose interests are, and are not, attended to and, in turn, discriminate what is, and is not, empirically tested by academics, attended to by managers or, regulated in practice." (Miles, 2015:2).

Friedman and Miles (2006) presented an early effort to sort, filter and structure this complex field of enquiry. At that time we saw stakeholder theory as reaching a crossroads, fuelled by enormous growth in popularity and uptake among academics, 
practitioners and policy makers but hampered by widespread misappropriation of the stakeholder concept that threatened its survival as a useful business concept. We reviewed 75 texts to determine the boundaries of what constitutes a stakeholder. This review, although somewhat hurried and unstructured, returned 55 different stakeholder definitions raising the question of how profuse, and confused the concept had become. At the time this represented the most comprehensive overview of the stakeholder concept.

In 2008 I embarked on a major review of the stakeholder concept to address this problem in a more systematic and comprehensive manner. This became a much larger, more time consuming project than I first envisaged, returning a seemingly impenetrable 1892 articles to review from the research protocol "To establish the range of stakeholder definitions using a review of works which have 'stakeholder(s)' in the title, published in high quality academic management journals, up to and including 2008". This created a database of 563 definitions, of which 435 were discrete instantiations. The initial findings from the analysis formed the basis of my paper presented at the EIASM $1^{\text {st }}$ interdisciplinary conference on stakeholders, resources and value creation (Miles, 2011). At the same conference I also presented the preliminary findings of a paper on the stakeholder concept as an essentially contested concept (ECC) according to the philosophy of Gallie (1956), which was subsequently published (see Miles, 2012). ECCs are not just ambiguous or radically confused concepts subject to substantial semantic arguments, but those in which the arguments involve substantive perpetual political arguments. Recognition of the stakeholder concept as an ECC has important consequences for theory development and I will return to this point later. The database was updated in 2012 evidencing 593 different interpretations from 885 definitions. 
Does it matter if there are hundreds of instantiations? If Mitchell, Agle, and Wood (1997) had access to the entire population of stakeholder definitions would they have concluded that power, legitimacy and urgency are the only necessary attributes for stakeholder recognition? Are the potentials for threat or co-operation (Savage, Nix, Whitehead and Blair, 1991) the only considerations necessary for stakeholder strategy formulation? Likewise are the centrality of the focal organization and the density of the stakeholder network sufficient considerations for assessing stakeholder influencing strategies (Rowley, 1997)? This logic applies to all stakeholder models: the more informed we are about what constitutes a stakeholder the more robust ensuing stakeholder theories will be and the potential for misinterpretation and distortion (Phillips et al., 2003) will be reduced.

What is needed is a meta-theory for stakeholder theory. Such a meta-theory should consider the nature and limits of, and relationship between, stakeholder determinants so that resulting theories and practices are theoretically sound and internally consistent. This requires a conceptual exploration, or philosophical discussion, of the foundations and structure of stakeholder theory. There is a risk that, in the absence of a meta-theory, the increased complexity associated with multicontextual applications increases the likelihood of misinterpreting, misunderstanding and misappropriating the stakeholder concept and stakeholder theory in general. A meta-theory prescribes what is acceptable (and unacceptable) as a theory. It would underpin stakeholder theory by enabling an assessment of how stakeholder theory has developed and how it should develop in future. The starting point for any meta-theory is a conceptual enquiry into the underpinning concepts and principles. 
This chapter proposes the beginnings of a meta-theory for stakeholder theory by bringing together my previous research (Miles, 2011, 2012, 2015) to present a conceptual enquiry into the central stakeholder concept. Collectively this conceptual enquiry distinguishes between multi-contextual narratives, identifies sorts and orders the essential attributes required for stakeholder status, considers the implications of the stakeholder concept as an ECC and culminates in the first systematic, multidimensional classification of stakeholder theory and definitions, tested with positive effect. The chapter concludes with a discussion of implications for future stakeholder theory research.

\section{What is a Stakeholder?}

Freeman (1984) defined a stakeholder as any "group or individual who can affect, or is affected by, the achievement of a corporation's" (p.vi) or "organization' purpose" (p.54), “firm's objectives" (p.25), “organization's objectives" (p.46) or "performance” (p.iv). Whilst variants of these five subtly different definitions from his seminal text remains the most sited the collective view derived from management literature is far more complex. An all-inclusive definition would outline a stakeholder as a group (or a coalition, collective, market, neighborhood, network, publics or society), individual (or actor, agent, constituent, member, participant, partner, party or vector) or entity (institution, corporate or organization) that may be a human (person or citizen) or non-human (the environment, natural entity or God) even anyone or anything. Stakeholders may be allies, beneficiaries, benefit providers, benefit receivers, value chain participants, claimants, risk bearers or risk providers. A stakeholder is recognized if it is strategic or significant, identifiable, concrete, political or visible. Stakeholders may be past (nonliving), present or future (potential, an unborn foetus or future generations). 
Stakeholders may be affected by (influenced by, or impacted by) an organization (or association, business, company, cooperative, corporation, enterprise, entity, firm, focal organization or manager). The nature of the impact could be that the stakeholder hurts or is harmed (suffers) as a consequence of the relationship, has its rights violated or that it benefits or gains from having its rights respected. Stakeholders may also affect (influence or impact) an organization (association etc.) positively by investing resources to create value, benefits, wealth or to make a difference or by providing assistance (help, support or promotion) through its contribution (participation or co-operation) or negatively by threatening, opposing, damaging, harming, hurting or hindering an organization (association etc.) directly or through imposing a critical eye or mobilising opinion. The affect (impact etc.) may be on the organization's (association etc.) objectives (or strategy, goals, purpose, function, mission or policies), actions (practices, activities, decisions or behavior), survival or failure (existence, ability to continue as a going concern or to exist) or outcome (performance, success, products, operations, value, welfare, bottom line, future, revenue, distributions, image or licence to operate). A relationship must be present whether in the form of a contact, exchange (deal, interaction or transaction) or collaboration (affiliation, involvement, engagement or joint endeavor) which may be firm dependent, stakeholder-dependent or interdependent. The relationship can be direct or indirect, voluntary or involuntary, external (outside) or internal (inside), critical (core, necessary or non-trivial) or distal (fringe), primary secondary tertiary, formal (official) or informal, perfect or imperfect, implicit or explicit, legal (contractual or arm's length), economic (financial), operational, social or moral (normative), legitimate, derivative or residual, market or non-market, joint and mutual. The relationship, which may or may not be mutually acknowledged or substantial, arises from a past, present or future interest, claim, stake, right, contract, bond, title, 
agreement, commitment, risk, personal or institutional goal. The interest (claim, stake, risk etc.) may be based on power, legitimacy or urgency, proximity or frequency of contact, derived from resource dependency of invested resources, ownership or fiduciary duty, sacrifice made or recognition that the stakeholder has something to lose, but may also be based on concern, beneficence, a duty of care, obligation, responsibility, fairness, because the stakeholder interest is held to have intrinsic value as determined by managerial values spiritualism, symbolism or organizational culture.

This overview of the stakeholder concept, taken from Miles (2011), ignores examples of stakeholders (supplier, customer, employee etc.) as it focuses on the attributes recognized by contributors as necessary or sufficient conditions for considering stakeholder status. Not all conditions are required for recognition. Definitions may present just one or two condition e.g. "having a contract" (Reed, 2002:168) or "explicit or implicit claimant" (Roberts and Mahoney, 2004:402), or multiple conditions: "classes of stakeholders can be identified by their possession or attributed possession of one, two, or all three of the following attributes: the stakeholder's power to influence the firm, the legitimacy of the stakeholder's relationship with the firm, and the urgency of the stakeholder's claim on the firm" (Mitchell et al., 1997:854). Different conditions exist because stakeholder theory has developed from multiple narratives with different purposes and different definitions are generated to serve these purposes. The recognition of the complexity illustrated above evidences, indisputably, the existence of the definitional problems that many stakeholder theorists have alluded to, or partially illustrated.

As stakeholder theory develops and the term 'stakeholder' is disseminated across disciplines it is inevitable that the definition will become susceptible to change. The elaboration of definitions is, therefore, a positive and expected consequence of the 
development of discourse. Early modification is predicated on the basis of extending the boundaries of stakeholder recognition. For example, SRI (1963) identified stakeholders as "those groups without whose support the organization would cease to exist", presenting a strategy focused perspective. The concept of the stakeholder having a 'stake' in the business was not proposed until 1979: "stakeholder groups consist of people who are affected by corporate policies and practices and who see themselves as having a stake in the business" (Sturdivant 1979: 54). It was a decade later that Alkhafaji (1989:36) advocated an ethics based definition: "Groups to whom the corporation is responsible". In the 1990s focus turned to explaining how stakeholders can impact organizations and why organizations attend to their interests and this was also reflected in definitions. More recent modification is driven by a desire to express more precisely what contributors are trying to communicate through the inclusion of adjectives or adverbs, for instance in debates concerning whether responsibility should be moral, legal or derivative.

A degree of conceptual confusion will exist in any field of enquiry. As the discipline matures it is expected that some agreement regarding the boundary limits of its central concept will be reached. This is not so for an ECC as further debate about the best instantiation of the construct can be perfected but never resolved. The following section provides a brief overview of the stakeholder concept as an ECC, based largely on Miles (2012).

\section{'Stakeholder' as an Essentially Contested Concept}

Gallie (1956) proposed that some concepts such as art, religion and democracy are ECCs. ECCs relate to ideas where there is widespread acceptance of a concept but disagreement on the best interpretation of it. ECCs involve substantive perpetual 
political arguments (Jacobs, 2006), not just semantic disputations associated with ambiguity or conceptual confusion. Parties to the debate acknowledge alternative instantiations and recognize that their own use is contested by others.

The starting point is a conceptual enquiry. For an ECC there are two levels of meaning apparent (Jacobs, 2006). The first level of meaning, referred to as the 'common core' (Swanton, 1985), is undisputed for an ECC: “even people holding widely different views agree what the subject is when using a certain term, as there are no other terms expressing the same set of core ideas" (Miles, 2012:286). For the stakeholder concept the common core is the organization-stakeholder relationship. Contestability occurs at the second level of meaning imparted in operationalising the concept, which differs because of the different "weightings given to various components of a concept, according to the ideology and social positioning of the definer" (Miles, 2012:288).

An ECC must meet five necessary conditions (Gallie, 1956), which I applied to the stakeholder concept in the following way: Firstly the ideological framework of adopting a stakeholder theory approach to running an organization is associated with many benefits and so is deemed to be appraisive in nature. Secondly the stakeholder concept is internally complex in character as it is a multi-faceted concept involving multiple components which are assigned different degrees of importance according to the ideology and social positioning of the definer.

Thirdly an ECC must be variously describable. Whilst this is apparent from the discussion of 'what is a stakeholder' above, I illustrated this by organising the various necessary and sufficient conditions of stakeholder status according to the following questions, summarizing the various approaches applied in the literature:

i. Who are the stakeholders?

ii. Who is identifying the stakeholder? 

iii. How the stakeholder impacts the organization?
iv. How the organization impacts the stakeholder?
v. Why are the stakeholders being identified?
vi. What is the form of the stake?
vii. What is the nature of the stake?
viii. What does the stake relate to?

In addition stakeholder theories are so diverse that they have been subject to categorisation, for example instrumental, descriptive and normative theories (Donaldson and Preston, 1995) first, second and third order normative theories (Hendry, 2001; Friedman and Miles, 2006) and via segment of strategy formulation process (Friedman and Miles 2002).

The fourth necessary condition is that the stakeholder concept is open in character being subject to considerable modification in the light of changing circumstances. The stakeholder concept has developed over time as diverse fields have embraced it. Early definitions focused on formulation of strategic objectives that emphasized the support of primary stakeholders as necessary for corporate survival or as influencers. This remained so throughout the 1970s, reflecting a stable business environment. Freeman (1984) highlighted the need to understand how and why stakeholder groups arise and how strategically corporations should respond to them during the turbulent business environment of the 1980s. This necessitated a symmetric perspective on stakeholder identification that considers both stakeholder impact on the organization and organizational impact on its stakeholders. The concept developed in the 1990s and new models emerged that aimed to assist corporations in stakeholder management, focusing on salience (Mitchell et al., 1997) or mobilization (Rowley, 
1997), for example. The growing pressures, post-millennium on organizations to become more socially responsible has further widened the stakeholder concept to include more claimant definitions based on informal or implicit contracts.

Finally, an ECC must be used aggressively and defensively as each party contests the instantiations of others and, in turn, recognizes that their instantiations are similarly contested. This is true with respect to stakeholder theory as many authors recognize the confusion, if not the contestability of the concept, by devoting valuable word count to discussing, defining and rejecting multiple definitions.

Gallie (1956) also proposed two justifying conditions to differentiate ECCs from those concepts that are 'radically confused': 1) that the concept has derived from an original authoritative exemplar and 2) that continuous debate will lead to sharpening of the analytic framework over time, referred to as optimal development. The first condition is met as stakeholder theory has a recognized and sustained original exemplar in Freeman (1984). There are also progressive improvements evident in conceptual clarification, quality of arguments and depth of enquiry (see Freeman et al. (2010) and Friedman and Miles (2006) for overviews). I concluded, on the basis of the evidence provided, that "the stakeholder concept is an essentially contested concept, rather than merely ambiguous, or confused" (Miles, 2012: 295).

What is the significance of treating the stakeholder concept as an ECC?

i. The stakeholder concept is, and will remain, subject to continued political debate over the best instantiation of the construct. Debate exists at the second level of meaning over how the concept should be interpreted in practice.

ii. As an ECC, a single, universal definition is not achievable, or even desirable.

iii. Such debates can never be resolved but are capable of rational resolution through argument with a greater awareness and understanding of one's 
arguments and how these relate to alternative narratives. This is required for optimal development of stakeholder theory.

iv. Optimal development requires a demarcation of boundaries that delineate different classes of definitions stemming from divergent voices. A classification system providing guidance on definitional boundaries would help to reduce, and explain, contestability by ordering and grouping similarities of approach into manageable classes. It is classification that I turn to next, drawing largely from Miles (2015).

\section{'Classification Systems' in Stakeholder Theory}

As stakeholder theory has developed there have been many attempts to sort and categorize definitional approaches. The most common are dichotomous groupings, although some multiple distinctions are also suggested (Table 1). With the exception of Mitchel et al. (1997), who recognized the convergence of attributes (power, legitimacy and urgency), these examples suggest an either/or categorisation rather than a subtle mix of variables. Nevertheless they represent ideas about ordering stakeholder determinants which could be further explored in developing of a more sophisticated classification.

\section{Insert Table 1 here}

Kaler (2002) presented the first categorisation of definitional approaches, grouping types of stakeholder definitions into three groups: 'claimant' (requiring a claim on a business), 'influencer' (requiring a capacity to influence business), or 
'combinatory' definitions (capturing both attributes). This demonstrated insight into the stakeholder concept but was simplistic, drawing only on the 27 stakeholder definitions identified in Mitchell et al. (1997). Consequently many stakeholder determinants evident in the 885 definitions subsequently identified are overlooked. Definitions based on risk (e.g. Clarkson, 1994), firm-specific investment (e.g. Schneper and Guillén, 2004), interaction (e.g. Maignan, O.C. Ferrell and L. Ferrell, 2005), or relationships (e.g. Thompson, Wartick and Smith, 1991) are unclassifiable. This accounts for $30.5 \%(n=181)$ of definitions identified in my database.

I addressed this problem with a systematic and comprehensive classification of stakeholder theory, based on classification theory and created from in-depth analysis of all 885 stakeholder definitions identified. I deconstructed the definitions into a database totalling 20,680 words and analysed these according to the 8 questions derived in the ECC paper. This generated 205 definitional variables and 9,201 data points. The form of classification system developed needed to be consistent with consideration of the stakeholder concept as an ECC, whereby there is agreement at the 'first level of meaning' of the stakeholder concept (the core function of the object), but political disagreements at the 'second level of meaning' (how to operationalize it in practice). There are many forms of classification approaches, with 'overall similarity' and 'essentialism' at the extremes. Essentialism was eventually selected as this accommodates both levels of meaning for an ECC. At the first level of meaning the core function of a stakeholder is the organization-stakeholder relationship. This aligns with the essentialist conceptualisation of 'what it is to be an object'; the attributes necessary to identification of a concept and its function. The substantive arguments at the second level of meaning provided sufficient conditions for stakeholder recognition. These are complex and overlapping so it was important that the classification system permitted 
the convergence of attributes rather than defining absolute categories of stakeholders. Unlike overall similarity, essentialism does not require precise factor coefficients to be assigned enabling the recognition of the convergence of stakeholder attributes. Determination of precise factor coefficients would be problematic for a classification of stakeholder theory as attributes are not mutually exclusive, taxonomic distance between factors is indeterminate and disputed, and weightings, or importance given to different attributes is disputed.

Extensive knowledge of the field is a prerequisite for an effective classification system. Two broad debates were identified which, when juxtaposed, formed the sorting constructs. The first observation made was that debates are mainly organization-centric with only a few contributors explicitly focusing on the stakeholder's perspective. This has important consequences for the attributes recognized for stakeholder identification. Nineteen issues were identified with respect to stakeholder identification from the perspective of management (MPD and MPRA) but only 3 of these reflect the stakeholder's perspective (SPD and SPRA) as illustrated in Figure 1.

\section{Insert Fig. 1 here}

The second observation made was that some arguments focus on boundary conditions for recognition (e.g. nature of the stake or risk) whereas other arguments are more concerned with refining relationship attributes (e.g. the form of interaction or level of interdependency). These can be thought of as input determinants and output attributes of the organization-stakeholder relationship. Such contributions were initially sorted and categorized into arguments about similar issues. For example 21 different issues relating to the form of contract, claim, stake etc. required for 
stakeholder identification were apparent, ranging from contractual, economic or legal claims to spiritual, weak or self-perceived claims (Figures 2 and 3).

As an ECC, the stakeholder concept is considered variously describable with different weightings afforded by different appraisers. I believe these all exist along a continuum rather than being absolute, depending on ideology, social and strategic positioning and are subject to change. For some attributes there was a straightforward determination to reflect antonyms e.g. wide or narrow strategic focus or reciprocated or unreciprocated relationships. For managerial perceived determinants (MPD) this continuum is a normative-strategic one. Looking, for example, at nature of the organizational obligation to stakeholders in figure 2, fiduciary duties (De Bussy, Watson, Pitt and Ewing, 2000) are more strategic than advocacy, guardianship or managerial values (Knox \& Gruar, 2007), which are less normative than moral obligations (Brenner,1993) or obligations based on fairness. (Phillips, 2003).

In order to create distinct classes of shareholders all 19 factors were sorted along a number of continuums and then juxtaposed into a single model that demonstrated how these debates relate to each other. This created 4 stakeholder hyponyms:

1. Influencer

2. Claimant

3. Collaborator

4. Recipient

Insert Fig. 2 and Fig 3 here

i. An influencer stakeholder has the capacity to influence the actions of an organization and has an active strategy to do so. Influencer stakeholders are 
associated with a high potential propensity to harm (SPRA3) or co-operate (MPRA10), utilitarian power (MPD6) to influence (affect, interfere, impact, etc.(MPRA2)) an organization and an active (SPRA1) and direct (SPRA2) strategy to do so based on critical, probable and time sensitive claims (SPD1). Propensity to influence increases with the density of stakeholder networks (MPRA7) and with organizational centrality within the network (MPRA4). Legitimacy (MPD3) is derived from explicit legal, contractual or formal claims based on economic transactions (MPD1), giving rise to a fiduciary or perfect obligation (MPD2) to have their concerns reciprocated (MPRA9). Due to the potential impact of influencers management will seek frequent contact (MPRA5) and transparent communication (MPRA3) as part of stakeholder management practices. Not all stakeholder definitions that indicate influence are influencer definitions as a distinction should be made between active influence (influencer), passive influence (collaborator), the potential to influence (claimants) and no influence (recipients). Pure influencer definitions, therefore, must be asymmetric in scope. This view contrasts with Kaler (2002) who combined the extent to which stakeholders can exert an influence on an organization with a corresponding influence the organization can exert on the stakeholder. An example of an influencer definition is Phillips et al. (2003:481) "those who can assist or hinder the achievements of the organization's objectives"

ii. A claimant stakeholder has a claim on an organization and an associated active strategy to pursue the claim but lacks the power to guarantee that the claim is attended to by management. Claimants are differentiated from recipients by an active strategy to pursue the claim (SPRA1) and, from influencers, as claims may be derived from moral, social or residual rights (MPD1). Legitimacy is achieved 
through moral responsibility (MPD3) or a duty of care (MPD4). Consequently claimants lack the coercive power (MPD6) to guarantee that claims are attended to. Recognition of a claimant requires a wide strategic focus (MPRA1) as claimants are not vital for survival (MPRA8) and the level of reciprocity is low (MPRA9). An example of a claimant definition is Carroll (1989:22) "individuals or groups with which business interacts who have a 'stake' or vested interest in the firm. This 'stake' is also described as a 'claim', 'interest' or 'right"'

iii. A collaborator stakeholder co-operates with an organization but lacks an active influencing strategy. Collaborator definitions are those which identify stakeholders through their ability to co-operate (MPRA9) with organizations but adopt a passive (SPRA1) indirect (SPRA2) influencing strategy, as claims lack urgency or criticality (SPD1). An example of a collaborator definition is "Participants in the human process of joint value creation" (Freeman, 1994:415).

iv. A recipient stakeholder is affected by the operation of an organization but does not actively pursue any claims (SPRA1). Recipients may be impacted involuntarily (MPDA5) through mere existence, such as local communities experiencing pollution. Implicit, imperfect or weak claims, based on voluntary benevolence (MPD1) are difficult to identify and so stakeholders may not be aware that they have a claim. Alternatively recipients may lack power (MPD6) to press claims or choose to remain silent if claims are associated with non-critical issues (SPD1). An example of a recipient definition is Clarkson's (1994:5) conceptualisation as stakeholders as those that "Are placed at risk as a result of a firm's activities" 
The classification model is presented in Fig.4. Whilst this provides four clear hyponyms which stakeholder definitions can be categorised by, this model demonstrates far more as it illustrates how the various aspects and complex ideas that constitute stakeholder theory actually relate to each other and fit together. It has been questioned whether stakeholder theory is actually a theory or merely an amalgamation of eclectic narratives (Gilbert and Rasche, 2008). Phillips et al. (2003) clarified many issues in identifying critical distortions and friendly misinterpretations in their efforts to establish boundaries over what stakeholder theory is, and is not. They argued that stakeholder theory is a theory of organizational management and ethics and is distinct from other theories in that it explicitly addresses morals and values as a central feature of managing organizations. This is clearly evident throughout the literature which is captured in figure 4: both managerial perceived determinants and attributes centre around morals and values, whether expressed as the nature of power, the nature of claims or the reciprocity of a relationship etc.. Whilst there may be subtle arguments surrounding the degree of normativity versus instrumentality, it is indisputable that stakeholder theory is centred around morals and values. The proposed model illustrates how the 'amalgamation of narratives' relate to each other within a single stakeholder theory.

Insert Fig. 4 here

Claimant, influencer, recipient and collaborator classes are not mutually exclusive and, in addition to the four distinct classes, eleven potential combinations of genres exist, suggesting 15 genres in total. The classification model was subsequently tested using the 885 definitions. Definitions were classified into all fifteen genres. The 
results are reproduced from Miles (2015) in figure 5. The influencer based definitions are the most popular (520) followed by recipient (445), claimant (268) and then collaborator (217). This is due, in part, to Freeman's (1984) seminal contribution as the original exemplar of stakeholder theory as an ECC, as 221 definitions included the influencer-based concept 'can affect' and 288 definitions adopted variants of the recipient attribute 'is affected by'

The majority (540) of definitions were classified as combinatory. This is expected for an ECC and is indicative of perpetual debate over attributes and associated weightings. An example of a combinatory definition is Merrilees, Getz and 0'Brien (2005:1063-4) who proposed that stakeholder identification is based on three salient features: "Interdependence; 2) affecting/being affected by the organization; and 3) the sense of an interest or right in the organization". Most combinatory definitions captured two genres with only 32 definitions representing very wide all-inclusive approaches. Wide definitions lack practical application and, as greater definitional clarification is achieved through debate, should diminish over time.

My classification model did not accommodate all 885 definitions as 11 were included as 'unclassifiable'. This was because unclassifiable definitions were identified by absent characteristics whereas the classification model was developed from necessary or sufficient conditions that must be present. Many unclassifiable definitions were comparative, for example defining secondary stakeholders by reference to how they compare to primary stakeholders, in that they lack a formal contract or are not essential for survival. This kind of definition fails to delineate sufficient conditions for identification as they infer that anybody/anything that does not have certain 
characteristics would be afforded stakeholder status. I recommended avoiding this approach.

Insert Fig. 5 here

A classification system is an important development for an ECC as it conveys meaning beyond that arising from individual debates around a concept and provides sharper analysis. This should lead to a reduction in contestability as the array of determinants and relationship attributes advocated by individual contributors, stemming from a range of narratives associated with stakeholder theory, are evaluated, categorized and juxtaposed within one model, highlighting the extent of interconnectedness or divergence.

As aforementioned, recognition of the stakeholder concept as an ECC indicates that a universally accepted definition can never be achieved. To achieve optimal development future debate concerning the best instantiation of the stakeholder concept should logically shift from endless debates around generic definitions to refined debates aligned with stakeholder genres that share similar characteristics stemming from similar ideologies. To this end contributors need to work towards gaining consensus at the second level of meaning which, in turn, will enable researchers to align their contribution more readily with others.

\section{Concluding thoughts}

As stakeholder theory matures there is a greater need to consider the role and refinement of theory in providing perspective on optimal development. What I have 
presented here is, essentially, the starting point for a comprehensive meta-theory for stakeholder theory. Stakeholder theory has faced many criticisms, not at least in terms of the ambiguity of its central construct. In addressing such concerns this chapter summarises and combines the findings from three projects which are all associated with an in-depth exploration of the basic foundations of stakeholder theory: i) a philosophical exploration of the stakeholder concept as an essentially contested concept (Miles, 2012); ii) a systematic review of stakeholder definitions (Miles, 2011), and; iii) the development of a classification system derived from an evaluation, analysis, sorting and ordering of the stakeholder literature (Miles, 2015). These collectively contribute to a meta-theory for stakeholder theory. A meta-theory identifies the characteristics of the determinants that constitute a stakeholder in order to prescribe what is acceptable (and unacceptable) as stakeholder theory in an attempt to address the concern that if stakeholder theory is to remain viable it requires stronger theoretical foundations (Phillips et al., 2003).

This conceptual enquiry has addressed a number of interrelated fundamental questions. Each question has direct consequences for the next and so there is a logical necessity to deal with each layer systematically and consistently. Such questions included: Who are the stakeholders? What is the form of the stake? What is the nature of the stake? What does the stake relate to? Who is identifying the stakeholder? Why are the stakeholders being identified? How does the stakeholder impact the organization? How does the organization impact the stakeholder? Only by answering fundamental questions can more advanced issues in operationalising stakeholder management be addressed. For example, in order to develop a predictive stakeholder theory the basic tenets needs to be clearly understood in terms of how issues and factors relate and 
interconnect. Only then can the consequences of strong and weak forms of stakeholder management be empirically tested.

The meta-theory for stakeholder theory is intended to provide a set of interlocking principles which provide an underpinning logic of consistency for what is needed from stakeholder theory and what should, logically, determine the nature and scope of stakeholder management. An overview of a conceptual enquiry into the stakeholder concept has been presented to provide a context so that readers can understand the extent and range of diversification evident within the boundaries of stakeholder theory and to appreciate how different approaches relate to each other rather than conflict with each other. Theorizing leads to a common understanding of the nature and alignment of stakeholder determinants and thereby guides future development through explanation, evaluation and critique of theory, promote consistency in reasoning. There has been marked effort in terms of theoretical clarification; however, conceptual exploration at the meta-theory level has been absent.

It is apposite to think about and debate the conceptual foundations of stakeholder theory now. The inevitable application of further multi-disciplinary approaches will add increasing complexity to the underpinning principles, which are dependent on clear boundaries for stakeholder identification. In the absence of a metatheory further complexity will intensify the opportunities to misinterpret, misunderstand and misappropriate the stakeholder concept and stakeholder theory.

\section{Implications for future research}

It is hoped that this conceptual enquiry will provide a springboard for debate and contribute to optimal development "to render a stronger and more convincing theory as a starting place for future research" (Phillips et al., 2003:479). There are a number of 
implications for future research, as one would expect from the exploratory development of a meta-theory:

1. Focus on the implications for future research is exceedingly important for optimal development of stakeholder theory. Debates about the best instantiation of an ECC can never be resolved but arguments can be perfected. Some definitions are better than others. Those definitions which define terms by reference to necessary or sufficient conditions are superior to those that define a stakeholder by reference to examples, synonyms or to what an expression is not.

2. Future researchers should specify for what purpose a definition is being proposed, acknowledge the contestability of the concept, the consensus view, and, the authority of Freeman's original exemplar, even if these factors are subject to dispute and further debate. In order to understand the meaning of the stakeholder concept as an ECC one needs to examine the vested interests and context from which it arose and the context into which it fits.

3. As the level of analysis has deepened it is apparent that all aspects of stakeholder recognition are subject to contestation, albeit some more than others. Future research could examine which stakeholder attributes are subject to the greatest degree of contestability, whether particular debates are associated with particular genres or hyponyms and how definitions have evolved. Further applications of the stakeholder classification model at key intervals would enable researchers to assess changes in contestability over time. In addition the assessment of those concepts (definitions) that fall outside of stakeholder theory where the stakeholder concept is misappropriated or misunderstood would be facilitated through further evaluation of definitional boundaries of what are deemed necessary and sufficient conditions for stakeholder recognition. 
4. An interesting area for further research lies in the evaluation of stakeholderorganization relationship from the perspective of the stakeholder. Classification constructs highlighted the organization-centric nature of extant research. Greater understanding on the stakeholder-organization relation from the stakeholder perspective would benefit management by reducing the expectation gap over issues such as accountability, responsibility and transparency.

5. Finally, the meta-theory presented should be extended to determine whether those who use the expression follow the same rules to ensure that stakeholder theory is internally consistent. As an ECC the stakeholder concept is subject to different desires and beliefs as what is necessary to bring about the desired consequences. Differing narratives may present valid alternatives but it is important to acknowledge that they may present different premises and result in different conclusions. Consequently consistency in reasoning is imperative. The model presented, whilst robust and comprehensive, is the first effort to classify an exceptionally complex field. This system was based on management literature and so alternative worldviews could be explored, such as public policy or the environmental sciences, as these may propose alternative classifications which capture alternative variables in determining stakeholder recognition. 


\section{REFERENCES}

Aaltonen K, and Kujala, J. (2010). A project lifecycle perspective on stakeholder influence strategies in global projects. Scandinavian Journal of Management, 26, $381-97$.

Agle, B.R., Mitchell, R.K. and Sonnenfeld, J.A. (1999). Who matters to CEOs? An investigation of stakeholder attributes and salience, corporate performance and CEO values. Academy of Management Journal, 42(5), 507-25.

Alkhafaji, A.F. (1989). A Stakeholder Approach to Corporate Governance; Managing in a Dynamic Environment. Westport CT: Quorum Books.

Atkinson, A.A., Waterhouse, J.H., and Wells, R.B. (1997). A stakeholder approach to strategic performance measurement. Sloan Management Review, Spring, 25-37.

Barton, S.L., Hill, N.C. and Sundaram, S. (1989). An empirical test of stakeholder theory predictions of capital structure. Financial Management, 18, 36-44.

Bosse, D.A., Phillips, R.A. and Harrison, J.S. (2009). Stakeholders, reciprocity, and firm performance. Strategic Management Journal, 30, 447-56.

Bourne L. and Walker, D.H.T. (2005). Visualising and mapping stakeholder influence. Management Decision, 43, 649-60.

Bowmann-Larsen, L. and Wiggen, O. (2004). Responsibility in World Business: Managing Harmful Side-Effects of Corporate Activity. USA: United Nations University Press.

Brenner S.N. (1993). The stakeholder theory of the firm and organizational decision making: Some propositions and a model, in Pasqueroa, J. and Collins, D. (Eds.), Proceedings of the Fourth Annual Meeting of the International Association for Business and Society. San Diego. 
Burton, B.K. and Dunn, C.P. (1996). Feminist ethics as a moral grounding for stakeholder theory. Business Ethics Quarterly, 6(2), 133-47.

Carroll, A.B. (1989). Business \& Society: Ethics and Stakeholder Management, Cincinnati: South-Western Publishing Company.

Choi, Y.R. and Shepherd, D.A. (2005). Stakeholder perceptions of age and other dimensions of newness. Journal of Management, 31, 573-96.

Clarkson, M.E. (1994). Risk-Based Model of Stakeholder Theory. Toronto: The Centre for Corporate Social Performance and Ethics.

Clarkson, M.E. (1995). A stakeholder framework for analyzing and evaluating corporate social performance. Academy of Management Journal, 20(1), 92-118.

Darnall, N., Henriques, I. and Sadorsky, P. (2010). Adopting proactive environmental strategy: the influence of stakeholders and firm size. Journal of Management Studies, 47(6), 1072-94.

De Bussy, N.M., Watson, T., Pitt, L.F., and Ewing, M.T. (2000). Stakeholder communication management on the internet: an integrated matrix for the identification of opportunities. Journal of Communication Management, 5(2), 13846.

Donaldson, T. and Preston, L.E. (1995). The stakeholder theory of the corporation: concepts evidence and implications. Academy of Management Review, 20, 65-92.

Driscoll, C. and Starik, M. (2004). The primordial stakeholder: advancing the conceptual consideration of stakeholder status for the natural environment. Journal of Business Ethics, 49, 55-74.

Emshoff, J.R. and Freeman, R.E. (1978). Stakeholder management. Working paper July, Wharton Applied Research Center, University of Pennsylvania. 
Evan, W.M. and Freeman R.E. (1988). A stakeholder theory of the modern corporation: Kantian capitalism, in Beauchamp, T.L. and Bowie N.E. (Eds.), Ethical Theory and Business. Englewood Cliffs NJ: Prentice Hall.

Fassin, Y. (2009). The stakeholder model refined. Journal of Business Ethics, 84, 113-35. Ferrell, O.C. and Ferrell, L. (2009). An enterprise-wide strategic stakeholder approach to sales ethics. Journal of Strategic Marketing, 17(3-4), 257-70.

Fineman, S. and Clarke, K. (1996). Green stakeholders: industry interpretations and response. Journal of Management Studies, 33(6), 715-30.

Freeman, R.E. (1984). Strategic Management: A Stakeholder Approach. Boston: Pitman Publishing.

Freeman, R.E. (1994). The politics of stakeholder theory: Some future directions. Business Ethics Quarterly, 4, 409-21.

Freeman, R.E. and Reed, D.L. (1983). Stockholders and stakeholders: a new perspective on corporate governance. California Management Review, 25(3), 88-106.

Freeman, R.E., Harrison, J.S., Wicks, A.C., Parmar, B.L. and DeColle, S. (2010). Stakeholder Theory: The State of the Art. Cambridge University Press, New York.

Friedman, A.L. and Miles, S. (2006). Stakeholders: Theory and Practice. Oxford University Press, Oxford.

Friedman, A.L. and Miles, S. (2002). Developing stakeholder theory. Journal of Management Studies, 39(1), 1-21.

Friedman, M. (1970). The social responsibility of a firm is to increase its profits. The New York Times Magazine, 13 September, 33.

Frooman, J. (1999). Stakeholder influence strategies. Academy of Management Review, 24, 191-205. 
Frost, F.A. (1995). The use of stakeholder analysis to understand ethical and moral issues in the primary resource sector. Journal of Business Ethics, 14, 653-61.

Gallie, W.B. (1956). Essentially contested concepts. Proceedings of the Aristotelian Society, 56, 167-98.

Gilbert, D.U. and Rasche, A. (2008). Opportunities and problems of standardised ethics initiatives: a stakeholder theory perspective. Journal of Business Ethics, 82, 755773.

Goodpaster, K.E. (1991). Business ethics and stakeholder analysis. Business Ethics Quarterly, 1(1), 53-73.

Hart, S.L. and Sharma, S. (2004). Engaging fringe stakeholders for competitive imagination. Academy of Management Executive, 18, 7-18.

Henriques, I., and Sadorsky, P. (1999). The relationship between environmental commitment and managerial perceptions of stakeholder importance. Academy of Management Journal, 42(1), 87-99.

Heugens, P.P.M.A.R. and van Oosterhout, H. (2002). The confines of stakeholder management: evidence from the Dutch manufacturing sector. Journal of Business Ethics, 40, 387-403.

Hill, C.W.L. and Jones, T.W. (1992). Stakeholder-agency theory. Journal of Management Studies, 29(2), 131-54.

Holtbrügge, D., Berg, N., and Puck, J.F. (2007). To bribe or to convince? Political stakeholders and political activities in German multinational corporations. International Business Review, 16, 47-67.

Hummels, H. (1998). Organizing ethics: a stakeholder debate. Journal of Business Ethics, $17,1403-19$. 
Jacobs, M. (2006). Sustainable development as a contested concept, pp.21-45 in Dobson,

A., Fairness and Futurity: Essays on Environmental Sustainability and Social Justice, Oxford University Press, Oxford.

Jahansoozi, J. (2006). Organization-stakeholder relationships: exploring trust and transparency. Journal of Management Development, 25(10), 942-55.

Jensen, M.C. (1983). Organization theory and methodology. Accounting Review, April, 319-39.

Jensen, M.C. (2001). Value Maximisation, stakeholder theory, and the corporate objective function. European Financial Management, 7(3), 297-317.

Jones, T.M. and Wicks, A.C. (1999). Convergent stakeholder theory. Academy of Management Review, 24(2), 206-21.

Kaler, J. (2002). Morality and strategy in stakeholder identification. Journal of Business Ethics, 39, 91-100.

Kaler, J. (2003). Differentiating stakeholder theories. Journal of Business Ethics, 46, 7183.

Kaufman, A. and Englander, E. (2011). Behavioral economics, federalism, and the triumph of stakeholder theory. Journal of Business Ethics, 102, 421-38.

Knox, S., and Gruar, C. (2007). The application of stakeholder theory to relationship marketing strategy development in a non-profit organization. Journal of Business Ethics, 75, 115-35.

Kochan, T.A and Rubinstein, S.A. (2000). Towards a stakeholder theory of the firm: the Saturn approach. Organization Science, 11, 367-86.

Langtry, B. (1994). Stakeholders and the moral responsibilities of the firm. Business Ethics Quarterly, 4, 431-43. 
Laplume, A. O., Sonpar, K., and Litz, R. A. (2008). Stakeholder theory: Reviewing a theory that moves us. Journal of Management, 34 (6), 1152-1189.

Lawrence, A.T. (2010). Managing disputes with nonmarket stakeholders: wage a fight, withdraw, wait, or work it out? California Management Review, 53(1), 90-113.

Luoma, P. and Goodstein, J. (1999). Research notes: stakeholders and corporate boards: institutional influences on board composition and structure. Academy of Management Journal, 42(5), 553-63.

Madsen, H. and Ulhøi, J.P. (2001). Integrating environmental and stakeholder management. Business Strategy \& the Environment, 10(2), 77-88.

Magness, V. (2008). Who are the stakeholders now? An empirical examination of the Mitchell, Agle, and Wood theory of stakeholder salience. Journal of Business Ethics, 83, 177-92.

Mahoney, J. (1994). Stakeholder responsibilities: turning the ethical tables. Business Ethics: A European Review, 3/4, 31-5.

Maignan, I., Ferrell, O.C. and Ferrell, L. (2005). A stakeholder model for implementing social responsibility in marketing. European Journal of Marketing, 39, 956-977.

Mainardes, E. W., Alves, H. and Raposo, M. (2012). A model for stakeholder classification and stakeholder relationships. Management Decision, 50(10), 1861-79

Maranville, S.J. (1989). You can't make steel without having some smoke: A case study in stakeholder analysis. Journal of Business Ethics, 8, 57-63.

Marcoux, A.M. (2003). A fiduciary argument against stakeholder theory. Business Ethics Quarterly, 13, 1-24.

Merrilees B., Getz, D. and O’Brien, D. (2005). Marketing stakeholder analysis: Branding the Brisbane goodwill games. European Journal of Marketing, 39, 1060-77. 
Miles, S. (2011). Stakeholder definitions: profusion and confusion. EIASM $1^{\text {st }}$ interdisciplinary conference on stakeholders, resources and value creation, IESE Business School, University of Navarra, Barcelona.

Miles, S. (2012). Stakeholders: Essentially contested or just confused? Journal of Business Ethics, 108, 285-98.

Miles, S. (2015). Stakeholder theory classification: A theoretical and empirical evaluation of definitions. Journal of Business Ethics, 1-23, doi:10.1007/s10551015-2741-y

Miller R.L. and Lewis, W.F. (1991). A stakeholder approach to marketing management using the value exchange models. European Journal of Marketing, 25(8), 55-68.

Mir, M.Z. and Rahaman, A.S. (2011). In pursuit of environmental excellence: A stakeholder analysis of the environmental management strategies and performance of an Australian energy company. Accounting, Auditing \& Accountability Journal, 24(7), 848-78.

Mitchell, R.K. (2012). Book review: Stakeholder theory: impacts and prospects. Organization Studies 33(10), 1407-11.

Mitchell, R.K., Agle, B.R. and Wood, D.J. (1997). Towards a theory of stakeholder identification and salience: Defining the principle of who and what really counts. Academy of Management Review, 22, 853-886.

Mitroff, I.I. (1983). Stakeholders of the Organizational Mind. San Francisco: Jossey-Bass. Murray, K.B. and Vogel, C.M. (1997). Using a hierarchy-of effects approach to gauge the effectiveness of corporate social responsibility to generate goodwill toward the firm: financial versus non-financial impacts. Journal of Business Research, 38, 141-59. 
Neville, B.A., and Menguc, B. (2006). Stakeholder multiplicity: Toward an understanding of the interactions between stakeholders. Journal of Business Ethics, 66, 377-91.

Nuti, D.M. (1997). Democracy and economy: What role for stakeholders? Business Strategy Review, 8(2), 14-20.

O’Higgins, E.R.E. (2010). Corporations, civil society, and stakeholders: an organizational conceptualization. Journal of Business Ethics, 94, 157-76.

Ojala, J., and Luoma-aho, V. (2008). Stakeholder relations as social capital in early modern international trade. Business History, 50(6), 749-64.

Pfeffer, J. and Salancik, G.R. (1978). The External Control of Organizations: A Resource Dependence Perspective. New York: Harper and Row.

Phillips, R.A. (1997). Stakeholder theory and a principle of fairness. Business Ethics Quarterly, 7, 51-66.

Phillips, R.A. (1999). On stakeholder delimitation. Business \& Society, 38, 32-4.

Phillips, R.A. (2003). Stakeholder legitimacy. Business Ethics Quarterly, 13, 25-41.

Phillips, R.A., Freeman, R.E., and Wicks, A.C. (2003). What stakeholder theory is not. Business Ethics Quarterly, 13(4), 479-502.

Polonsky, M.J. and Ottman, J. (1998). Stakeholders' contribution to the green new product development process. Journal of Marketing Management, 14, 533-57.

Polonsky, M.J., Carlson, L., and Fry, M.L. (2003). The harm chain: A public policy development and stakeholder perspective. Marketing Theory, 3(3), 345-64.

Post, J.E., Preston, L.E. and Sachs, S. (2002). Redefining the Corporation: Stakeholder Management and Organizational Wealth. Stanford, CA: Stanford University Press.

Roberts, R.W. and Mahoney, L. (2004). Stakeholder conceptions of the corporation: Their meaning and influence in accounting research. Business Ethics Quarterly, $14,399-431$. 
Rowley, T.J. (1997). Moving beyond dyadic ties: A network theory of stakeholder influences. Academy of Management Review, 22, 885-910.

Sachs, S. and Maurer, M. (2009). Toward dynamic corporate stakeholder responsibility. Journal of Business Ethics, 85, 535-44.

Savage, G.T., Nix, T.W., Whitehead, C.J. and Blair, J.D. (1991). Strategies for assessing and managing organizational stakeholders. Academy of Management Executive, 5(2), 61-75.

Schneider, M. (2002). A stakeholder model of organizational leadership. Organization Science, 13(2), 209-20.

Schneper, W.D., and Guillén, M. (2004). Stakeholder rights and corporate governance: A cross-national study of hostile takeovers. Administrative Science Quarterly, 49, 263-95.

Shaoul, J. (1998). Critical Financial Analysis and Accounting for Stakeholders. Critical Perspectives on Accounting, 9, 235-49.

Sirgy M.J. (2002). Measuring corporate performance by building on the stakeholder's model of business ethics. Journal of Business Ethics, 35, 143-62.

SRI (Stanford Research Institute) (1963). Internal memo (unpublished). Stanford Research Institute, California, USA.

Starik, M. (1995). Should trees have managerial standing? Towards stakeholder status for nonhuman nature. Journal of Business Ethics, 14, 207-17.

Sternberg, E. (1997). The defects of stakeholder theory. Corporate Governance: An International Review, 5, 3-10.

Swanton, C., (1985). On the "Essential Contestedness" of Political Concepts. Ethics, 95(4), 811-827. 
Thompson, J.K., Wartick, S.L. and Smith, H.L. (1991). Integrating corporate social performance and stakeholder management: Implications for a research agenda in small business. Research in Corporate Social Performance and Policy, 12, 20730.

Trinkaus J. and Giacalone, J. (2005). The silence of the stakeholders: Zero decibel level at Enron. Journal of Business Ethics, 58, 237-48.

Turnbull, S. (1994). Stakeholder democracy: redesigning the governance of firms and bureaucracies. Journal of Socio-Economics, 23, 321-61.

Unerman, J. and Bennett, M. (2004). Increased stakeholder dialogue and the internet: towards greater corporate accountability or reinforcing capital hegemony? Accounting Organizations \& Society, 29, 685-707.

Vazquez-Brust, D.A., Liston-Heyes, C., Plaza-Úbeda, J.A. and Burgos-Jiménez, J. (2010). Stakeholders pressures and strategic prioritisation: An empirical analysis of environmental responses in Argentinean firms. Journal of Business Ethics, 91, 171-92.

Vinten, G. (2000). The stakeholder manager. Management Decisions, 38, 377-83.

Wicks A.C., Gilbert D.R. Jr., and Freeman R.E. (1994). A feminist reinterpretation of the stakeholder concept. Business Ethics Quarterly, 4, 475-97.

Zattoni, A. (2011). Who should control a corporation? Toward a contingency stakeholder model for allocating ownership rights. Journal of Business Ethics, $103,255-74$. 
Fig. 1: Stakeholder Perceived Determinants (SPD) and Stakeholder Perceived Relationship Attributes (SPRA) of Stakeholder Identification

\section{Stakeholder Perceived Determinants (SPD)}

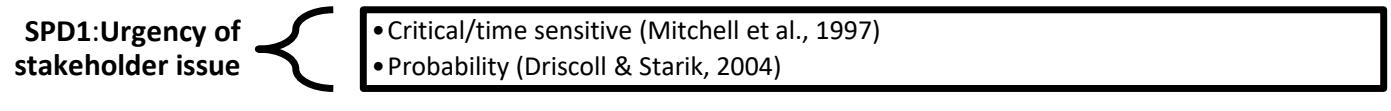

\section{Stakeholder Perceived Relationship Attributes (SPRA)}

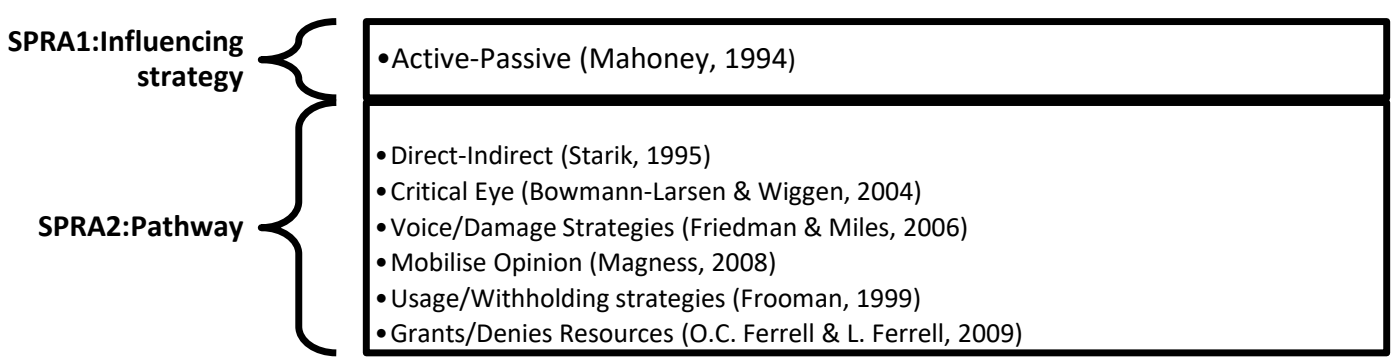

Source: Miles (2015) 
Fig. 2: Managerial Perceived Determinants of Stakeholder Identification

\begin{tabular}{|c|c|}
\hline $\begin{array}{r}\text { MPD1 } \\
\text { Form of claim, interest, stake } \\
\text { etc. }\end{array}$ & $\begin{array}{l}\text { - Arm's length (Marcoux, 2003) } \\
\text { - Contractual/Official (Savage et al., 1991); Non-contractual (Aaltonen \& Kujala, 2010) } \\
\text { - Conventional/Manifest/Representational/Evidential (Trinkaus \& Giacalone , 2005) } \\
\text { - Direct (Schneper \& Guillén, 2004); Indirect (Trinkaus \& Giacalone, 2005) } \\
\text { - Derivative (Phillips, 2003) } \\
\text { - Economic (Friedman, 1970); Social (Unerman \& Bennett, 2004) } \\
\text { - Explicit-Implicit (Jensen, 1983) } \\
\text { - Formal (Barton et al., 1989) Informal (Unerman \& Bennett, 2004) } \\
\text { - Identifiable (Lantry, 1994); Self-perceived (Madsen \& Ulhøi, 2001) } \\
\text { - Independent (Neville \& Menguc, 2006) } \\
\text { - Involuntary-voluntary (Phillips, 1999) } \\
\text { - Investment (Clarkson, 1994) } \\
\text { - Legal-Moral (Carroll,1989) } \\
\text { - Material/Affiliated/Political/ Symbolic/Spiritual (Holtbrügge, Berg and Puck, 2007) } \\
\text { - Non-negotiable (Bourne \& Walker, 2005) } \\
\text { - Operational (Turnbull, 1994) } \\
\text { - Overlapping (Fineman \& Clarke, 1996) } \\
\text { - Ownership (Carroll, 1989) } \\
\text { - Real-Pschological (Vinten, 2000) } \\
\text { - Strong-weak (Kaler, 2002) } \\
\text { - Residual (Zattoni, 2011) }\end{array}$ \\
\hline Nature of relationship & $\begin{array}{l}\text { - Compatible/incompatible/necessary/contingent (Friedman \& Miles, 2002) } \\
\text { - Formal (Savage et al., 1991) informal (Murray \& Vogel, 1997) } \\
\text { - Primary-secondary (Savage et al., 1991) Tertiary (Miller \& Lewis, 1991) } \\
\text { - Official (Savage et al., 1991) } \\
\text { - Market (Nuti, 1997) Non-market (Lawrence, 2010) } \\
\text { - Fiduciary - non-fiduciary ( Goodpaster, 1991) } \\
\text { - Non-trivial (Brenner, 1993) }\end{array}$ \\
\hline $\begin{array}{r}\text { MPD3 } \\
\text { Basis of Legitimacy }\end{array}$ & $\begin{array}{l}\text { - Claim (Hill \& Jones, 1992) } \\
\text { - Contract (expressed/implied) (Donaldson \& Preston (1995) } \\
\text { - Derivative (Phillips, 2003) } \\
\text { - Direct market transaction-Indirect external exposure (Nuti, 1997) } \\
\text { - Exchange relationship (Hill \& Jones, 1992) } \\
\text { - Exchange transactions (Brenner, 1993) } \\
\text { - Financial-human capital (Mir \& Rahaman, 2011) } \\
\text { - Legal title/right -moral interest/right (Agle, Mitchell and Sonnenfeld, 1999) } \\
\text { - Moral responsibility (Brenner, 1993) } \\
\text { - Normative (Phillips, 2003) } \\
\text { - Objective - perceived (Aaltonen \& Kujala, 2010) } \\
\text { - Property rights (Mitchell et al., 1997) } \\
\text { - Risk (Goodpaster, 1991) } \\
\text { - Responsibility (Alkhafaji, 1989) }\end{array}$ \\
\hline $\begin{array}{r}\text { MPD4 } \\
\text { Nature of obligation, duty or } \\
\text { responsibility }\end{array}$ & $\begin{array}{l}\text { - Advocacy, Guardianship, Managerial values (Knox \& Gruar, 2007) } \\
\text { - Beneficence (O’Higgins, 2010) } \\
\text { - Culture (Ferrell \& Ferrell, 2009) } \\
\text { - Duty of care (Burton and Dunn, 1996) } \\
\text { - Fairness (Phillips, 2003) } \\
\text { - Fiduciary (De Bussy et al., 2000) } \\
\text { - Intrinsic value (Donaldson \& Preston, 1995) } \\
\text { - Moral (Brenner, 1993) } \\
\text { - Perfect -imperfect (Kaler, 2002) }\end{array}$ \\
\hline $\begin{array}{r}\text { MPD5 } \\
\text { Nature of risk }\end{array}$ & - Voluntary-involuntary (Clarkson, 1994) \\
\hline $\begin{array}{r}\text { MPD6 } \\
\text { Nature of Power }\end{array}$ & $\begin{array}{l}\text { - Utilitarian/Coercive/Normative (Mitchell et al., 1997) } \\
\text { - Formal/Economic/Political (Freeman \& Reed, 1983) }\end{array}$ \\
\hline
\end{tabular}


Fig. 3: Managerial Perceived Relationship Attributes of Stakeholder Identification

\begin{tabular}{|c|c|}
\hline MPRA1:Strategic Focus & -Wide (Broad)-Narrow (Freeman \& Reed, 1983) \\
\hline MPRA2: Form of Interaction & $\begin{array}{l}\text { - Affects (Emshoff \& Freeman, 1978) Affected by (Pfeffer and Salancik, 1978) } \\
\text { - Influences/ controls (Pfeffer \& Salancik, 1978) Influenced by (Maranville, 1989) } \\
\text { - Impacts (Brenner, 1993) Impacted by (Frost, 1995) } \\
\text { - Harms/Benefits (Phillips, 2003) } \\
\text { - Harmed by (Evan \& Freeman, 1988), Gains from (Rowley, 1997) } \\
\text { - Rights violated or respected (Evan \& Freeman, 1988) } \\
\text { - Helps/Hurts (Miller \& Lewis, 1991) } \\
\text { - Suffers from/ Hurt by (Schneider, 2002) } \\
\text { - Assists/hinders (Phillips et al., 2003) } \\
\text { - Constrain (Kaufman \& Englander, 2011) } \\
\text { - Contribute (Kochan \& Rubinstein, 2000) } \\
\text { - Cooperate/Threaten (Polonsky \& Ottman, 1998) } \\
\text { - Creates value (Freeman, 1994) } \\
\text { - Creates wealth (Post, Preston and Sachs, 2002) } \\
\text { - Interactive (Neville \& Menguc, 2006) } \\
\text { - Invests value (Goodpaster, 1991) } \\
\text { - Makes a difference/participates (Hummels, 1998) } \\
\text { - Promote/oppose (Aaltonen \& Kujala,2010) } \\
\text { - Support (SRI, 1963) } \\
\text { - Withholding (Frooman, 1999) } \\
\text { - Something to lose (Rowley, 1997) }\end{array}$ \\
\hline $\begin{array}{r}\text { MPRA3:Centrality of } \\
\text { organisation }\end{array}$ & -Central-Distal (Frooman , 1999) \\
\hline MPRA4:Frequency of contact & - Frequent-infrequent (Ojala \& Luoma-aho, 2008) \\
\hline $\begin{array}{l}\text { MPRA5: Proximity of } \\
\text { relationship }\end{array}$ & $\begin{array}{l}\text { - Core (Jones \& Wicks, 1999) Fringe (Hart \& Sharma, 2004) } \\
\text { - Inside (Atkinson et al. , 1997) Outside (Fineman \& Clarke , 1996) } \\
\text { - Internal -external (Mitroff , 1983) } \\
\text { - Proximity (Driscoll \& Starik, 2004); } \\
\text { - Distal (Sirgy, 2002) }\end{array}$ \\
\hline MPRA6: Density of networks & •High-Low (Rowley, 1997) \\
\hline $\begin{array}{l}\text { MPRA7: dependency of } \\
\text { organisation on stakeholder }\end{array}$ & $\begin{array}{l}\text { - Success (Starik, 1995) } \\
\text { - Bottom line (Henriques \& Sadorsky, 1999) } \\
\text { - Revenues (Shaoul , 1998) } \\
\text { - Performance (Freeman , 1984) } \\
\text { - Outcome (Starik, 1995) } \\
\text { - Value (Jensen, 1983) } \\
\text { - Welfare (Jensen, 2001) } \\
\text { - Survival (SRI, 1963) } \\
\text { - Existence (Rhenman, 1964, cited in Mitchell et al., 1997) } \\
\text { - Going concern (Clarkson, 1995) } \\
\text { - Future (Emshoff and Freeman, 1978) } \\
\text { - Purpose (Freeman, 1984) } \\
\text { - Objectives (Freeman \& Reed, 1983) } \\
\text { - Strategy (Darnall et al. , 2010) } \\
\text { - Licence to operate (Jahansoozi, 2006) } \\
\text { - Mission (Choi \& Shepherd, 2005) } \\
\text { - Resources (Firm dependent ) (Pfeffer \& Salancik, 1978) } \\
\text { - Stakeholder dependent (Langtry, 1994) }\end{array}$ \\
\hline $\begin{array}{r}\text { MPRA8: Reciprocity of } \\
\text { relationship }\end{array}$ & $\begin{array}{l}\text { - High-Low (Bosse et al., 2009) } \\
\text { - Interdependencies (Carroll , 1989) } \\
\text { - Joint (Freeman, 1994) } \\
\text { - Mutual benefit (Phillips, 1997) } \\
\text { - Mutually acknowledged (Heugens \& van Oosterhout, 2002) } \\
\text { - Mutually dependent (Wicks, Gilbert and Freeman, 1994) } \\
\text { - Reciprocal (Fineman \& Clarke, 1996) }\end{array}$ \\
\hline $\begin{array}{r}\text { MPRA9 : Propensity to } \\
\text { cooperate }\end{array}$ & $\begin{array}{l}\text { - High-Low (Freeman, 1984) } \\
\text { - Collaboration/Supportive-non supportive/marginal (Savage et al., 1991) }\end{array}$ \\
\hline MPRA10 Propensity to harm & $\begin{array}{l}\text { - High/Low Propensity to harm (Savage et al., 1991) } \\
\text { - Cause/Affected by harm (Polonsky, Carlson and Fry, 2003) } \\
\text { - Potential for Threat (Freeman, 1984) }\end{array}$ \\
\hline
\end{tabular}


Fig. 4: A Classification Model of Stakeholder Theory Definitions (Miles, 2015)

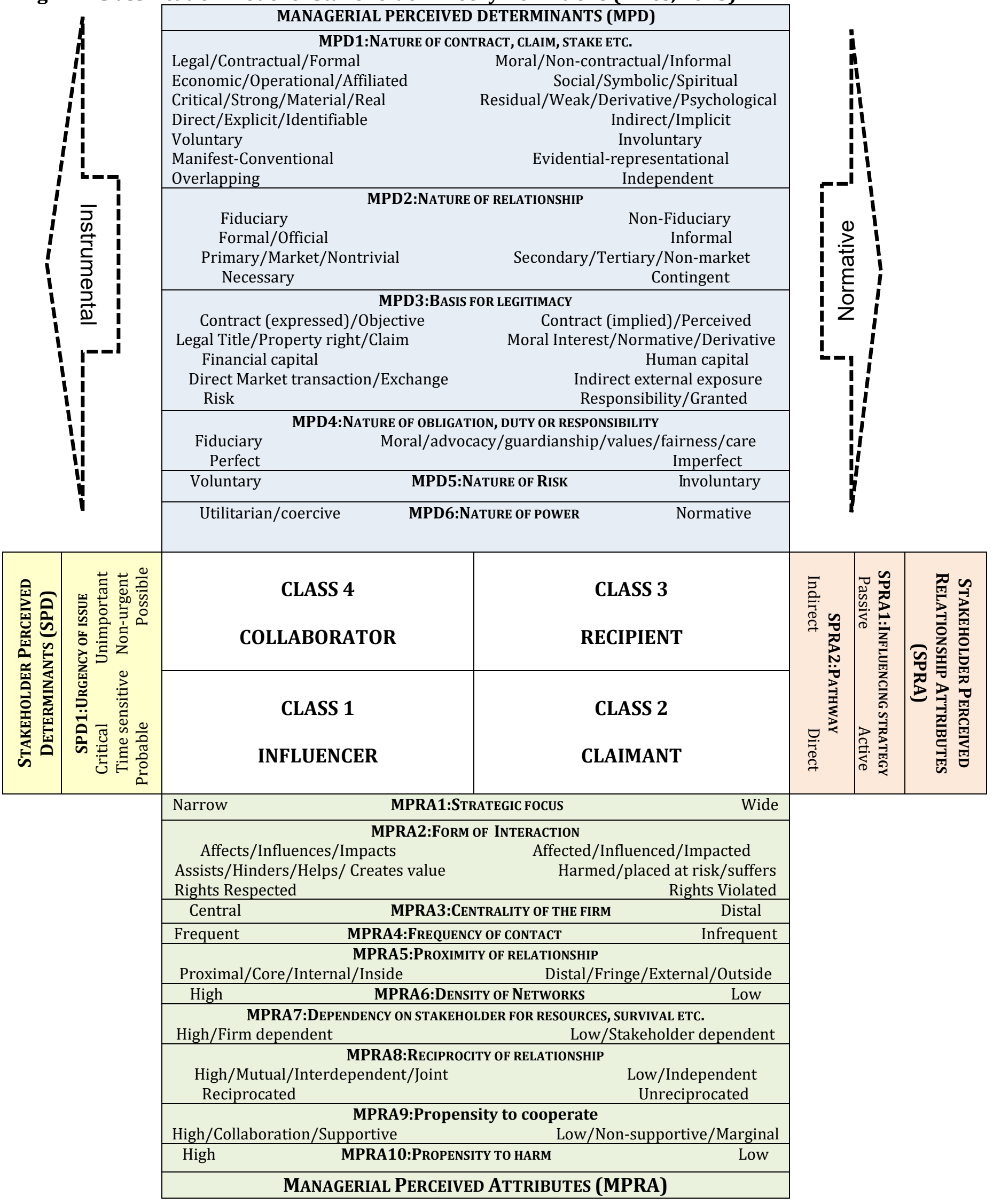


Fig. 5: Typology of stakeholder definitions and associated classification of 885 stakeholder definitions (n) ${ }^{1}$

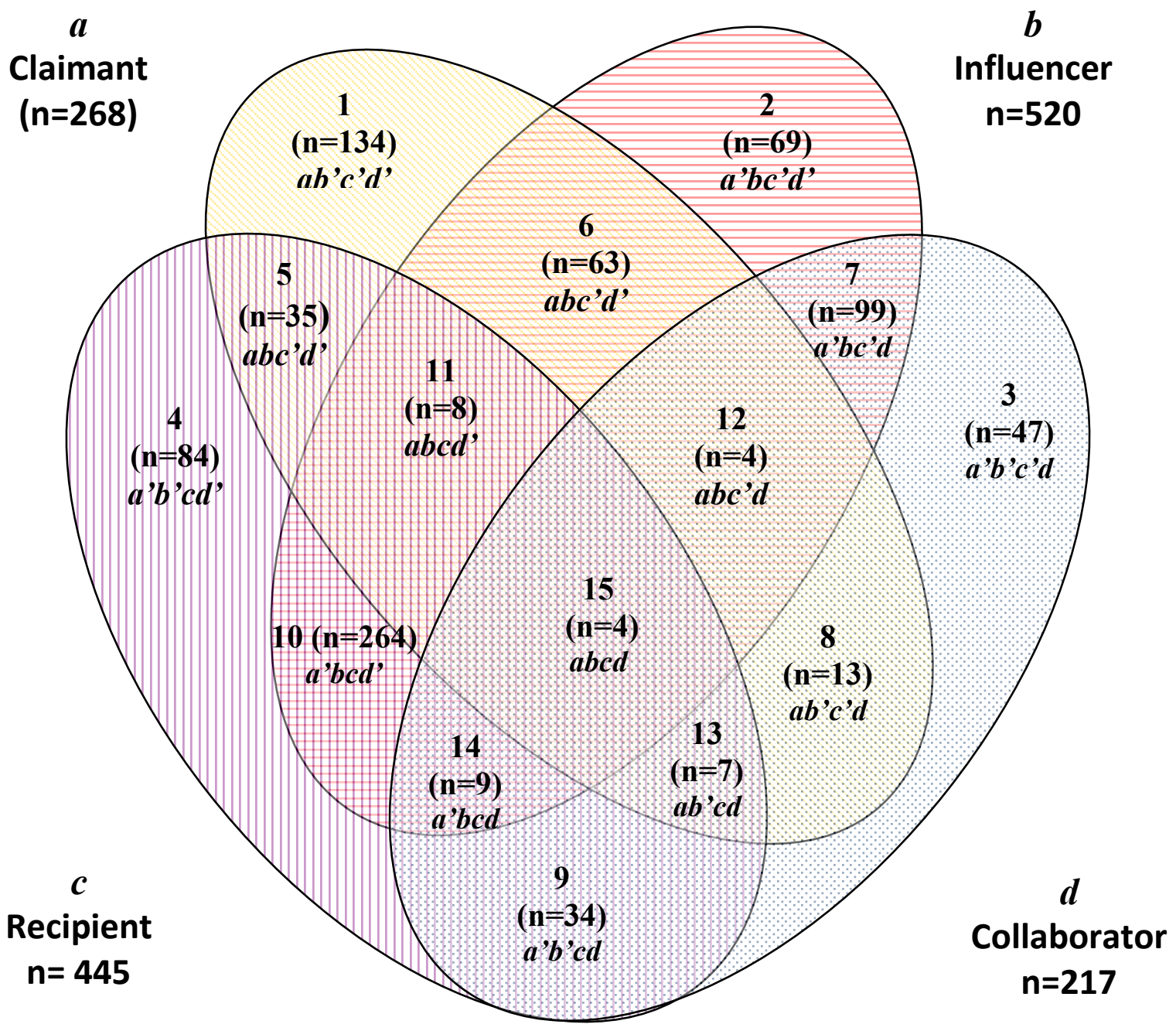

Unclassifiable $n=11$

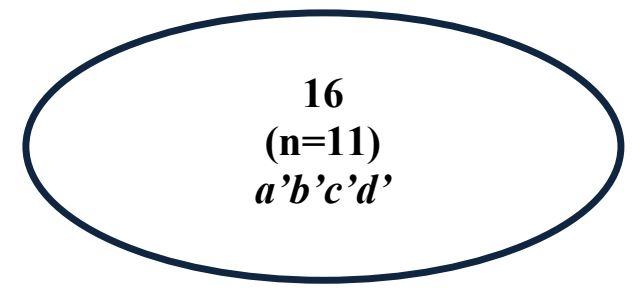

Source: Miles (2015)

\footnotetext{
1 The apostrophe is used to denote instances where definitions are not in a particular category i.e. a'bcd' refers to a definition that is not included in categories a and $\mathrm{d}$ but is included in $\mathrm{b}$ and $\mathrm{c}$.
} 
Table 1: Examples of Approaches to Sort Stakeholder Definitions

\begin{tabular}{|c|c|c|}
\hline Categorization of stakeholder definitions & Source & \\
\hline Wide/narrow & Freeman \& Reed & 1983 \\
\hline Primary/secondary & Savage et al. & 1991 \\
\hline Moral/strategic & Goodpaster & 1991 \\
\hline Active/passive & Mahoney & 1994 \\
\hline Voluntary/involuntary & Clarkson & 1995 \\
\hline $\begin{array}{l}\text { Definitive/dependent/dangerous/dominant/discretionary/ } \\
\text { demanding/dormant }\end{array}$ & Mitchell et al. & 1997 \\
\hline Primary/public & Luoma \& Goodstein & 1999 \\
\hline Organizational/community/regulatory/media. & Henriques \& Sadorsky & 1999 \\
\hline Necessary/contingent/compatible/incompatible & Friedman \& Miles & 2002 \\
\hline Internal/external/distal & Sirgy & 2002 \\
\hline Resource-based/industry structure-based/socio-political-based & Post et al. & 2002 \\
\hline Normative/derivative & Phillips & 2003 \\
\hline Core-fringe/peripheral & Hart \& Sharma & 2004 \\
\hline Stakeholder/stakewatcher/stakekeeper & Fassin & 2009 \\
\hline Benefit provider/risk provider/benefit receivers/ risk bearer. & Sachs \& Maurer & 2009 \\
\hline Institutional/organizational/social & $\begin{array}{l}\text { Vazquez-Brust, Liston-Heyes, } \\
\text { Plaza-Úbeda, J.A. and Burgos- } \\
\text { Jiménez }\end{array}$ & 2010 \\
\hline $\begin{array}{l}\text { Regulator/controller/partner/passive/dependent/non- } \\
\text { stakeholder }\end{array}$ & Mainardes, Alves and Raposo & 2012 \\
\hline
\end{tabular}

